\title{
https://doi.org/10.46813/2020-130-026 \\ EFFECTS OF ARGON ATOMS IN EXCITED STATES ON PROPERTIES OF ARGON-ACETYLENE DUSTY PLASMA
}

\author{
I.B. Denysenko, S. Ivko, N.A. Azarenkov, G. Burmaka \\ V.N. Karazin Kharkiv National University, Kharkiv, Ukraine \\ E-mail: idenysenko@yahoo.com
}

It is studied how dissociation and ionization of acetylene molecules in their collisions with argon atoms in excited states Ar* may affect properties of argon-acetylene plasma with growing inside of plasma volume dust particles. The study is carried out using a volume-averaged model. To analyze the effects of Ar* atoms on the electron and ion densities, the effective electron temperature and the densities of radical and nonradical neutral species, the values of ionization and dissociation rates for collisions of acetylene molecules with $\mathrm{Ar}^{*}$ atoms are varied in numerical calculations. It is found that the collisions of Ar* atoms with acetylene molecules affect essentially the argon-acetylene dusty plasma.

PACS: 52.27.Lw, 52.25.Ya, 52.20.Hv, 52.27.Cm, 82.33.Xj

\section{INTRODUCTION}

Reactive plasmas with growing inside of plasma volume nano- and micro- sized particles (dust particles) are of a great fundamental interest and are also useful for various technological applications [1]. Carbonaceous dust particles are usually formed in gas mixtures containing methane, acetylene or ethylene and, therefore, gas discharges in these gas mixtures have been investigated in many works [2-9].

Experiments in $\mathrm{Ar} / \mathrm{C}_{2} \mathrm{H}_{2}$ plasmas showed that formation of dust particles is accompanied by an increase of electron temperature and density of metastable argon atoms and by a decrease of electron and acetylene densities [3,4]. The degree of dissociation of acetylene in an $\mathrm{Ar} / \mathrm{C}_{2} \mathrm{H}_{2}$ plasma at growth of nanoparticles was found to be as high as $99 \%$ [5]. It was also shown that metastable argon atoms may affect essentially the electron density in argon and argon-acetylene dusty plasma afterglows [5, 6]. However, effects of excited argon atoms on properties of argon-acetylene plasma with growing inside of plasma volume dust particles are not well-studied at present. Moreover, the exact values for the rates describing ionization and dissociation of acetylene molecules in collisions with excited argon atoms are not known.

In this paper, we analyze how argon atoms in excited states, including those in the metastable states, affect the densities of ions, electrons and neutrals in an argonacetylene plasma with growing inside of plasma volume nanoparticles. The study is carried out using a volumeaveraged model. To analyze the effects of excited argon atoms on plasma properties, we vary in our calculations the magnitudes of the ionization and dissociation rates for collisions of acetylene molecules with excited argon atoms. The calculations are carried out for the same external conditions as in the experiments in [7,8].

\section{MAIN EQUATIONS AND ASSUMPTIONS}

We consider an argon-acetylene dusty plasma of $R=22 \mathrm{~cm}$ radius and $L=32.4 \mathrm{~cm}$ height, as in [7, 8]. The gas-discharge plasma consists of electrons with density $n_{e}$, seven positive ions with densities $n_{\alpha}^{+}$(where the index $\alpha=\mathrm{C}_{2} \mathrm{H}_{2}, \mathrm{Ar}, \mathrm{ArH}, \mathrm{C}_{4} \mathrm{H}_{3}, \mathrm{C}_{4} \mathrm{H}_{2}, \mathrm{C}_{6} \mathrm{H}_{4}, \mathrm{C}_{2} \mathrm{H}_{3}$ corresponds to the $\mathrm{C}_{2} \mathrm{H}_{2}{ }^{+}, \mathrm{Ar}^{+}, \mathrm{ArH}^{+}, \mathrm{C}_{4} \mathrm{H}_{3}{ }^{+}, \mathrm{C}_{4} \mathrm{H}_{2}{ }^{+}$, $\mathrm{C}_{6} \mathrm{H}_{4}{ }^{+}$and $\mathrm{C}_{2} \mathrm{H}_{3}{ }^{+}$ions, respectively), four nonradical and two radical neutrals with densities $n_{\alpha}$ (where the index $\alpha=\mathrm{Ar}, \mathrm{C}_{2} \mathrm{H}_{2}, \mathrm{H}_{2}, \mathrm{C}_{4} \mathrm{H}_{2}$ corresponds to the nonradical neutrals $\mathrm{Ar}, \mathrm{C}_{2} \mathrm{H}_{2}, \mathrm{H}_{2}, \mathrm{C}_{4} \mathrm{H}_{2}$, respectively, and $\alpha=\mathrm{C} 2 \mathrm{H}$, $\mathrm{H}$ is for the radicals $\mathrm{C}_{2} \mathrm{H}, \mathrm{H}$, correspondingly), negatively charged dust particles with density $n_{d}$, radius $a_{d}$ and charge $Z_{\mathrm{d}}$ (in units of elementary charge), and three negative ions $\mathrm{C}_{2} \mathrm{H}^{-}, \mathrm{C}_{4} \mathrm{H}^{-}$and $\mathrm{C}_{6} \mathrm{H}^{-}$with densities $n_{\mathrm{C} 2 \mathrm{H}}$, $n_{\mathrm{C} 4 \mathrm{H}-}$ and $n_{\mathrm{C} 6 \mathrm{H}-}$, respectively. The gas-discharge plasma also contains metastable argon atoms $\left(\mathrm{Ar}_{\mathrm{m}}\right)$ with density $n_{\mathrm{m}}$, argon atoms in the resonance $4 \mathrm{~s}$ states $\left({ }^{3} \mathrm{P}_{1}\right.$ and $\left.{ }^{1} \mathrm{P}_{1}\right)$ $\left(\mathrm{Ar}_{\mathrm{r}}\right)$ with density $n_{\mathrm{r}}$ as well as argon atoms in $4 \mathrm{p}$ states $(\operatorname{Ar}(4 p))$ with density $n_{4 \mathrm{p}}$. In this model, the metastable and resonance atom densities $n_{\mathrm{m}}, n_{\mathrm{r}}$ and $n_{4 \mathrm{p}}$ represent the density of a composite $\left({ }^{3} \mathrm{P}_{0}\right.$ and $\left.{ }^{3} \mathrm{P}_{2}\right)$ metastable level, the density of a composite $\left({ }^{3} \mathrm{P}_{1}\right.$ and $\left.{ }^{1} \mathrm{P}_{1}\right)$ resonance level and the density of a composite $4 p$ state, respectively.

For the conditions considered in this study, the dominant neutral species are argon atoms and their density $n_{A r} \approx P /\left(k_{B} T_{g}\right)$, where $P=4.2 \mathrm{~Pa}$ is the pressure of argon gas and $k_{B}$ is the Boltzmann constant. The input fluxes of acetylene and argon are taken to be $1.5 \mathrm{sccm}$ and $11.0 \mathrm{sccm}$, respectively, as in the experiment of our interest [7 -9]. It is assumed that the energy distribution for ions is Maxwellian, and that the ions and dust particles are at gas temperature $T_{g}(300 \mathrm{~K})$, while the electron energy distribution function (EEDF) $F$ is assumed to be Druyvesteyn-like [7, 9]. The EEDF has the following normalization $\int_{0}^{\infty} F(\varepsilon) d \varepsilon=1$ and determines the effective electron temperature $T_{\text {eff }}=(2 / 3 e) \int_{0}^{\infty} \varepsilon F(\varepsilon) d \varepsilon$, where $\varepsilon$ is the electron energy.

It is assumed that the plasma is quasineutral, or

$$
\sum_{\alpha} n_{\alpha}^{+}=n_{e}+n_{\mathrm{C} 2 \mathrm{H}-}+n_{\mathrm{C} 4 \mathrm{H}_{-}}+n_{\mathrm{C} 6 \mathrm{H}_{-}}+\left|Z_{d}\right| n_{d} .
$$

The density of a species $X$ (neutrals or ions) is calculated, using the balance equation 


$$
\frac{d n^{(X)}}{d t}=\sum_{i} R_{G, i}^{(X)}-\sum_{i} R_{L, i}^{(X)},
$$

where $R_{G, i}^{(X)}$ and $R_{L, i}^{(X)}$ are, respectively, the reactions' rates describing various generation and loss processes of the species $X$ and $t$ is the time. The model accounts for various processes of the loss and generation of the discharge species, including the processes on dust particles and plasma walls, the collisional processes in the bulk plasma, as well as the pumping of gas in and out of the chamber. The processes and their rates are described in $[7,9]$.

The effective electron temperature is found from the power balance equation

$$
\frac{d}{d t}\left(\frac{3}{2} e n_{e} T_{e f f}\right)=\frac{1}{V}\left(P_{a b s}-P_{l o s s}\right)
$$

where $P_{a b s}=9 \mathrm{~W}$ is the absorbed power as in [7], $V$ is the volume of the discharge chamber, the power loss $P_{\text {loss }}=P_{\text {coll }}+P_{\mathrm{w}}+P_{d}$, where $P_{\text {coll }}$ is the power loss due to elastic and inelastic electron-neutral collisions [7, 9], $P_{w}$ and $P_{d}$ are the power losses due to charged particle fluxes to the walls and to the dust particles, respectively $[7,9]$.

The dust charge $Z_{d}$ is found, assuming that the charging of dust particles is due to electron and ion fluxes onto their surfaces, taking into account for the non-Maxwellian shape of the EEDF and collisions of ions with neutrals in the sheaths around dust particles $[7,9]$.

Considering the collisions of argon atoms in excited states $\mathrm{Ar}^{*}\left(\mathrm{Ar}_{\mathrm{m}}, \mathrm{Ar}_{\mathrm{r}}\right.$ or $\left.\mathrm{Ar}(4 \mathrm{p})\right)$ with $\mathrm{C}_{2} \mathrm{H}_{2}$ and $\mathrm{C}_{4} \mathrm{H}_{2}$ molecules, we assume that there are the reactions accompanied by ionization and dissociation of acetylene molecules, as well as by only deexcitation of excited argon atoms: $\mathrm{Ar}{ }^{*}+\mathrm{C}_{2} \mathrm{H}_{2}\left(\mathrm{C}_{4} \mathrm{H}_{2}\right) \rightarrow \mathrm{C}_{2} \mathrm{H}_{2}{ }^{+}\left(\mathrm{C}_{4} \mathrm{H}_{2}{ }^{+}\right)+\mathrm{Ar}$ $+\mathrm{e}^{-}$with the rate $k_{\text {exc }} \cdot 1.8 \cdot 10^{-10} \mathrm{~cm}^{3} / \mathrm{s}, \mathrm{Ar}^{*}+\mathrm{C}_{2} \mathrm{H}_{2}\left(\mathrm{C}_{4} \mathrm{H}_{2}\right)$ $\rightarrow \mathrm{C}_{2} \mathrm{H}\left(\mathrm{C}_{4} \mathrm{H}\right)+\mathrm{Ar}+\mathrm{H}$ with the rate $k_{\mathrm{exc}} \cdot 3.5 \cdot 10^{-10} \mathrm{~cm}^{3} / \mathrm{s}$, Ar* $+\mathrm{C}_{2} \mathrm{H}_{2}\left(\mathrm{C}_{4} \mathrm{H}_{2}\right) \rightarrow \mathrm{C}_{2} \mathrm{H}_{2}{ }^{*}\left(\mathrm{C}_{4} \mathrm{H}_{2}{ }^{*}\right)+\mathrm{Ar}\left(\right.$ or $\mathrm{C}_{2} \mathrm{H}_{2}\left(\mathrm{C}_{4} \mathrm{H}_{2}\right)$ $+\mathrm{Ar}+\hbar \omega)$ with the rate $\left(1-k_{\mathrm{exc}}\right) \cdot 5.3 \cdot 10^{-10} \mathrm{~cm}^{3} / \mathrm{s}$, where $0 \leq k_{\mathrm{exc}} \leq 1$, in the model, $k_{\mathrm{exc}}$ is a parameter.

Note that the exact values of the rates for $\mathrm{Ar}^{*}-\mathrm{C}_{2} \mathrm{H}_{2}$ reactions are not known at present. In [10], [5] and [11], the rate describing electron production in Ar*- $\mathrm{C}_{2} \mathrm{H}_{2}$ collisions was taken to be $3.5 \cdot 10^{-10} \mathrm{~cm}^{3} / \mathrm{s}, 0.3 k_{\mathrm{q}}$ and $0.1 k_{\mathrm{q}}$, respectively, where $k_{\mathrm{q}}=5.6 \cdot 10^{-10} \mathrm{~cm}^{3} / \mathrm{s}$ [12]. Since the threshold energy for ionization of $\mathrm{C}_{2} \mathrm{H}_{2}$ is larger than that for dissociation of acetylene molecules, it is assumed here that the rate for dissociation of $\mathrm{C}_{2} \mathrm{H}_{2}$ in collisions with $\mathrm{Ar}^{*}$ atoms is nearly 2 times larger than the ionization rate. More information on the rates for various generation and loss processes, considered in our model, can be found in $[7,9]$.

The balance equations for neutrals and ions (2), the power balance equation (3) and the equation for dust charge are solved by using the DVODE package [13]. First, the system of first order differential equations is allowed to reach a steady state, i.e. $d / d t=0$, for the case when the dust particles are absent in the plasma. After reaching the steady state, it is assumed that the dust ra- dius increases linearly from 10 up to $70 \mathrm{~nm}$ at a fixed dust density $\left(\sim 10^{7} \mathrm{~cm}^{-3}\right)$ during $88 \mathrm{~s}$ (in agreement with experiment in [8]). At the end of the phase (when $a_{\mathrm{d}}=$ $70 \mathrm{~nm}$ ), we suppose that the dust particles leave the plasma (because of effect of different forces on the dust grains). After the particle leaving, it is assumed that the dust particles do not affect much the plasma $\left(n_{\mathrm{d}}=0\right)$ during next $20 \mathrm{~s}$. After that, a new growth cycle starts.

\section{NUMERICAL RESULTS}

Using the theoretical model presented in section 2, we have analyzed how the neutral, ion and electron densities and effective electron temperature in an $\mathrm{Ar} / \mathrm{C}_{2} \mathrm{H}_{2}$ plasma evolve as dust radius increases with time. These simulations have been performed for conditions similar to experiments on nanoparticle growth presented in [79]. To analyze how the plasma properties depend on collisions of excited argon atoms with acetylene molecules, we have varied in our calculations the coefficient $k_{\text {exc }}$, which determines the acetylene loss in collisions with Ar*

Carrying out these simulations, on the base of experimental observations [8], we have made the following assumptions concerning the time variation of $a_{d}$ : The duration of a nanoparticle-growth cycle is $108 \mathrm{~s}$. During the first $20 \mathrm{~s}$ (phase I), the nanoparticles do not modify any plasma properties (in the model, $a_{\mathrm{d}}=0$ ), while the dust radius increases linearly from $10 \mathrm{~nm}$ up to $70 \mathrm{~nm}$ at a fixed dust density for the next $88 \mathrm{~s}$ (phase II). At the end of a growth cycle, dust particles leave the plasma and a new growth cycle starts.

In Fig. 1, the densities of $\mathrm{C}_{2} \mathrm{H}_{2}, \mathrm{H}_{2}$ and $\mathrm{C}_{4} \mathrm{H}_{2}$ as a function of time are shown for different $k_{\text {exc }}$.
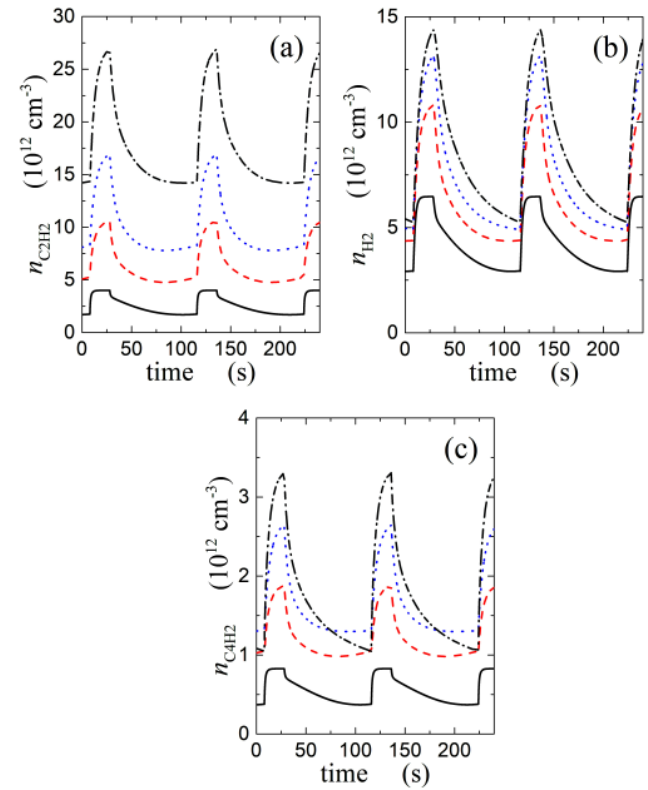

Fig. 1. The densities of $\mathrm{C}_{2} \mathrm{H}_{2}(a), \mathrm{H}_{2}(b)$, and $\mathrm{C}_{4} \mathrm{H}_{2}(c)$ for different $k_{\text {exc }}: 1.0$ (solid line), 0.5 (dashed line), 0.3 (dotted line), and 0.0 (dash-dotted line)

The time-dependencies are obtained assuming that the phases I and II start at $t=8 \mathrm{~s}$ and $t=28 \mathrm{~s}$, respectively, and the dust density in the phase II is $10^{7} \mathrm{~cm}^{-3}$. Note that Fig. 1 shows cycles taken in a middle of a long sequence (before $8 \mathrm{~s}$ it is the end of phase II from another cycle). One can see from Fig. 1,a that the acety- 
lene density decreases with increasing the coefficient $k_{\text {exc }}$. This is due to an enhancement of ionization and dissociation of $\mathrm{C}_{2} \mathrm{H}_{2}$ molecules in different collisions. In [14], it was shown that the loss of $\mathrm{C}_{2} \mathrm{H}_{2}$ molecules in the plasma is mainly due to their collisions with metastable atoms, positive ions, $\mathrm{C}_{2} \mathrm{H}$ radicals and electrons. The $\mathrm{C}_{4} \mathrm{H}_{2}$ and $\mathrm{H}_{2}$ production is related to the $\mathrm{C}_{2} \mathrm{H}_{2}$ density $[3,7]$, and, as a result, the densities of $\mathrm{C}_{4} \mathrm{H}_{2}$ and $\mathrm{H}_{2}$ also decrease with increasing $k_{\text {exc }}$ (excepting the case of small $k_{\text {exc }}$ and large times in phase II for $\mathrm{C}_{4} \mathrm{H}_{2}$ ) Figs. 1,b,c. In [9], the calculated time dependencies for $\mathrm{C}_{2} \mathrm{H}_{2}$ and $\mathrm{C}_{4} \mathrm{H}_{2}$ at $k_{\text {exc }}=0.5$ were found to be in a good qualitative agreement with those obtained by mass spectra measurements.

The densities of $\mathrm{C}_{2} \mathrm{H}_{2}, \mathrm{C}_{4} \mathrm{H}_{2}$, and $\mathrm{H}_{2}$ increase during phase I. For phase II and large $k_{\text {exc }}(\geq 0.3), \mathrm{C}_{2} \mathrm{H}_{2}$ and $\mathrm{C}_{4} \mathrm{H}_{2}$ densities are first decreasing, reach a minimum and then increase. For the case $k_{\mathrm{exc}}=0$, the densities of $\mathrm{C}_{4} \mathrm{H}_{2}$ and $\mathrm{H}_{2}$ are monotonically decreasing during phase II. The time dependency for $\mathrm{C}_{2} \mathrm{H}_{2}, \mathrm{H}_{2}$, and $\mathrm{C}_{4} \mathrm{H}_{2}$ is caused mainly by the time variation for argon atoms in excited states, for positive ions, $\mathrm{C}_{2} \mathrm{H}$ radicals and for electrons since the nonradical species are mainly lost in collisions with these species [14].
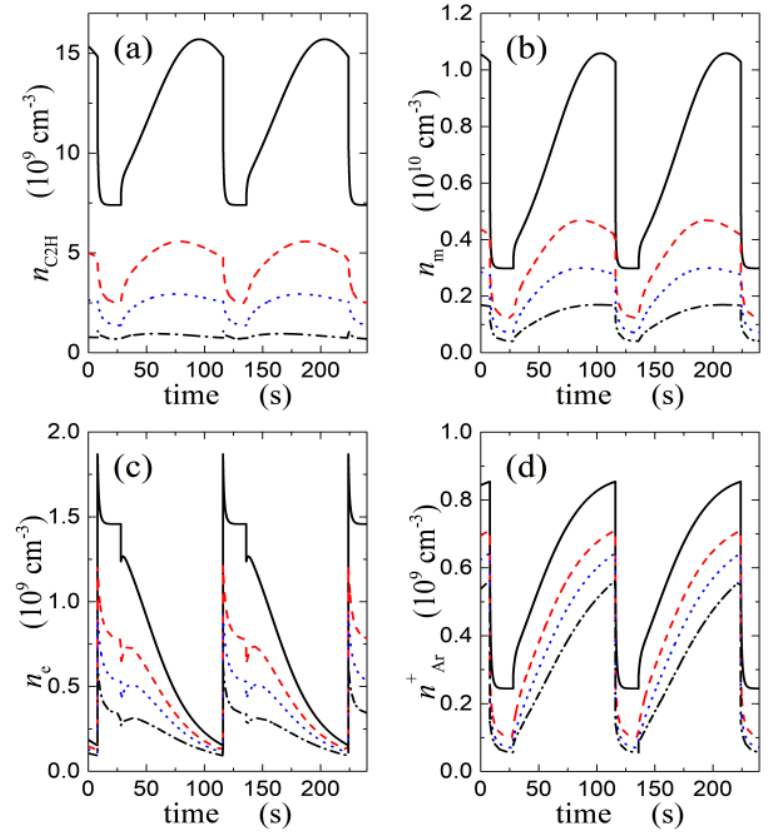

Fig. 2. The densities of $\mathrm{C}_{2} \mathrm{H}(\mathrm{a})$, argon metastable atoms

(b), electrons (c) and $A r^{+}$ions $(d)$ for different $k_{\text {exc }}$ :

1.0 (solid line), 0.5 (dashed line), 0.3 (dotted line) and 0.0 (dash-dotted line)

The decrease of the densities of nonradical species with increasing $k_{\mathrm{exc}}$ is accompanied by the increase of the densities of $\mathrm{C}_{2} \mathrm{H}$ radicals, metastable argon atoms and $\mathrm{Ar}^{+}$ions because of decreasing the losses of these species in collisions with neutrals (Fig. 2) and because of increasing $n_{\mathrm{e}}$ (see Fig. 2,c). The electron density increases with an increase of $k_{\mathrm{exc}}$ due to the decrease of the power loss in electron-neutral nonelastic collisions (since the densities of $\mathrm{C}_{2} \mathrm{H}_{2}, \mathrm{C}_{4} \mathrm{H}_{2}$, and $\mathrm{H}_{2}$ decrease and the input power is fixed). For $k_{\text {exc }} \neq 0$, the loss of $\mathrm{C}_{2} \mathrm{H}_{2}$ molecules is essentially affected by their collisions with excited argon atoms and $\mathrm{C}_{2} \mathrm{H}$ radicals $[7,14]$ and, as a result, the time dependencies for $\mathrm{Ar}_{\mathrm{m}}$ and $\mathrm{C}_{2} \mathrm{H}$ are near- ly inverse to that for acetylene molecules (see Figs. 2,a,b). The density of electrons drops with time for most of phase II (see Fig. 2,c) due to enhancement of electrons' collection by dust particles with increasing dust radius. The increase of dust radius is accompanied by the growth of the effective electron temperature (Fig. 3,a), which causes the increase of the density of argon ions in phase II (see Fig. 2,d).
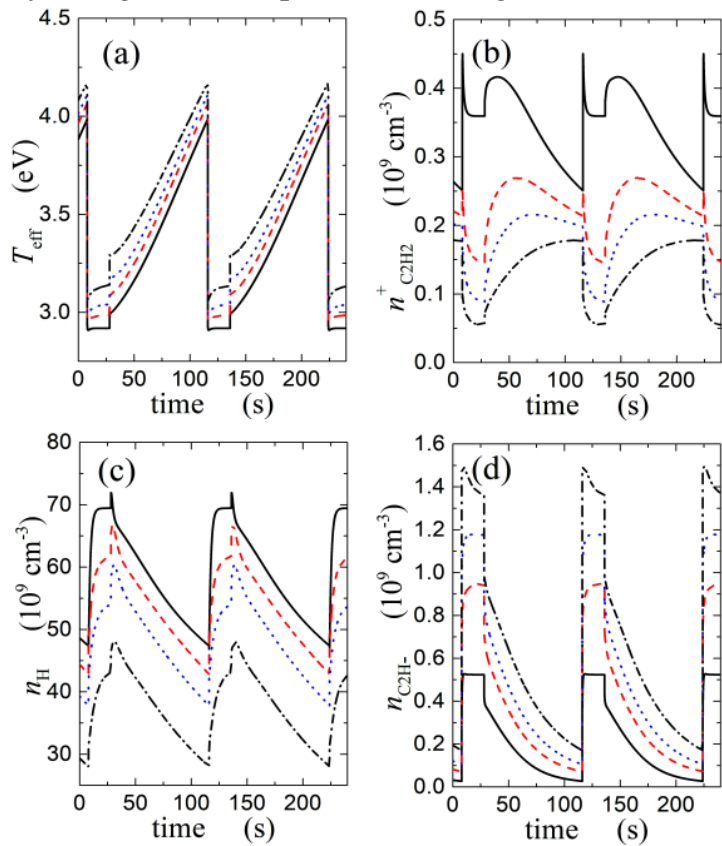

Fig. 3. The effective electron temperature (a) and the densities of $\mathrm{C}_{2} \mathrm{H}_{2}^{+}(b), \mathrm{H}(\mathrm{c})$, and $\mathrm{C}_{2} \mathrm{H}^{-}$(d) for different $k_{\text {exc }}: 1.0$ (solid line), 0.5 (dashed line), 0.3 (dotted line) and 0.0 (dash-dotted line)

The effective electron temperature becomes smaller with increasing $k_{\text {exc }}$ (see Fig. 3,a). In our opinion, the decrease of $T_{\text {eff }}$ is due decreasing the loss of electrons and positive ions in collisions with nonradical neutrals, since their densities decrease (see Fig. 1). Similarly to the $\mathrm{Ar}^{+}$density, the densities of $\mathrm{C}_{2} \mathrm{H}_{2}^{+}$ions and $\mathrm{H}$ radicals become larger with increasing $k_{\text {exc }}$. The increase is mainly due to enhancement of the production of these species in collisions of $\mathrm{Ar}^{+}, \mathrm{Ar}_{\mathrm{m}}$ and electrons (their densities increase) with neutral species and due to decrease of the loss of these species in collisions with neutrals species (their densities decrease). The density of negative ions $\mathrm{C}_{2} \mathrm{H}^{-}$decreases with increasing $k_{\text {exc }}$ (see Fig. 3) because the anion loss in collisions with positive ions and hydrogen atoms (which are the main loss mechanisms for $\mathrm{C}_{2} \mathrm{H}^{-}[14]$ ) becomes more intensive, as well as due to decreasing the acetylene density (the production of the anions is due to collisions of electrons with acetylene molecules). The density of $\mathrm{C}_{2} \mathrm{H}^{-}$anions is larger than the densities of $\mathrm{C}_{4} \mathrm{H}^{-}$and $\mathrm{C}_{6} \mathrm{H}^{-}$anions [9].

Note that the time-dependencies for $\mathrm{n}_{\mathrm{m}}$ and $\mathrm{C}_{2} \mathrm{H}_{2}{ }^{+}$ density at $k_{\mathrm{exc}}=0$ are slightly different from those obtained at $k_{\mathrm{exc}} \neq 0$. In particular, at large times of phase II, the densities of $\mathrm{Ar}_{\mathrm{m}}$ and $\mathrm{C}_{2} \mathrm{H}_{2}{ }^{+}$are increasing with time at $k_{\mathrm{exc}}=0$, while they decrease in the case $k_{\mathrm{exc}} \neq 0$.

In our opinion, this difference is due to the effects of $k_{\text {exc }}$ variation on the time dependencies for $\mathrm{C}_{2} \mathrm{H}_{2}$ and $\mathrm{C}_{4} \mathrm{H}_{2}$ (see Fig. 1). 


\section{CONCLUSIONS}

Thus, collisions of argon atoms in excited states with $\mathrm{C}_{2} \mathrm{H}_{2}$ and $\mathrm{C}_{4} \mathrm{H}_{2}$ molecules affect essentially properties of argon-acetylene dusty plasma. With increasing the acetylene loss in their collisions with Ar* (which is characterized here by the coefficient $k_{\text {exc }}$ ), the densities of $\mathrm{C}_{2} \mathrm{H}_{2}, \mathrm{C}_{4} \mathrm{H}_{2}$, and $\mathrm{H}_{2}$ decrease (see Fig. 1), while the density of electrons increases (see Fig. 2,c) because of decreasing the electron energy loss in collisions with neutrals. The increase of $n_{\mathrm{e}}$ is accompanied by increasing the densities of positive ions, excited argon atoms and $\mathrm{C}_{2} \mathrm{H}$ radicals (see Fig. 2) because the production of these species in collisions with electrons becomes more intensive. However, the density of negative ions decreases with increasing $k_{\text {exc }}$ (see Fig. 3,d). This is due decreasing the anion production in collisions with acetylene molecules $\left(n_{\mathrm{C}_{2} \mathrm{H}_{2}}\right.$ decreases) and due to enhancement of the anion loss in collisions with positive ions, those densities increase. Our calculations also show that the time dependences for plasma parameters obtained in the case of taking into account the dissociation and ionization of $\mathrm{C}_{2} \mathrm{H}_{2}$ and $\mathrm{C}_{4} \mathrm{H}_{2}$ molecules in their collisions with $\mathrm{Ar} *$ strongly differ from those obtained in the case when these processes are not taken into account. The results presented here are relevant to many applications involving reactive plasmas $[15,16]$, especially gas discharges used for the synthesis of various nanomaterials.

\section{REFERENCES}

1. Dusty Plasmas: Physics, Chemistry, and Technological Impacts in Plasma Processing / Edited by A. Bouchoule. New York: Wiley, 1999.
2. C. Deschenaux,
A. Affolter,
D. Magni,
C. Hollenstein, P. Fayet // J Phys. D: Appl. Phys. 1999, v. 32, p. 1876.
3. A.P. Herrendorf, V. Sushkov, R. Hippler // Journal of Applied Physics. 2017, v. 121, p. 123303.

4. J. Winter, J. Berndt, S.H. Hong, E. Kovačević, I. Stefanović, O. Stepanović // Plasma Sources Science and Technology. 2009, v. 18, p. 034010.

5. I. Stefanović, N. Sadeghi, J. Winter, B. Sikimić // Plasma Sources Science and Technology. 2017, v. 26, p. 065014.

6. I. Denysenko, I. Stefanović, B. Sikimić, J. Winter, N.A. Azarenkov, N. Sadeghi // J. Phys. D: Appl. Phys. 2011, v. 44, p. 205204.

7 I.B. Denysenko et al. // Plasma Phys. Control. Fusion. 2019, v. 61, p. 014014.

8. A.M. Hinz, E. von Wahl, F. Faupel, T. Strunskus, H. Kersten // J. Phys. D: Appl. Phys. 2015, v. 48, p. 055203.

9. I.B. Denysenko et al. // J. Phys. D: Appl. Phys. 2020, v. 53 , p. 135203.

10. F.J. Gordillo-Vazquez, J.M. Albella // J. Appl. Phys. 2003, v. 94, p. 6085.

11. L.G. Piper, J.E. Velazco, D.W. Setser // J. Chem. Phys. 1973, v. 59, p. 3323.

12. J.E. Velazco, J.H. Kolts, D.W. Setser // J. Chem. Phys. 1978, v. 69, p. 4357.

13. G.D. Byrne, S. Thompson. VODE_F90 Support Page, http://www.radford.edu/ thompson/vodef90web 14. I.B. Denysenko, E. von Wahl, S. Labidi, M. Mikikian, H. Kersten, T. Gibert// Plasma Processes and Polymers. 2019, v.16, p. 1800209.

15. I. Sereda, A. Tseluyko, N. Azarenkov, D. Ryabchikov, Ya. Hrechko // International Journal of Hydrogen Energy. 2017, v. 42, p. 21866.

16. Yu.A. Lebedev, A.V. Tatarinov, I.L. Epshtein // High Energy Chem. 2020, v. 54, p. 217.

Article received 27.09.2020

\section{ВЛИЯНИЕ АТОМОВ АРГОНА В ВОЗБУЖДЕННОМ СОСТОЯНИИ НА СВОЙСТВА АРГОН- АЦЕТИЛЕНОВОЙ ПЫЛЕВОЙ ПЛАЗМЫ}

\section{И.Б. Денисенко, С. Ивко, Н.А. Азаренков, Г. Бурмака}

Исследовано, как диссоциация и ионизация молекул ацетилена при их столкновении с атомами аргона в возбужденном состоянии Ar* могут влиять на свойства аргон-ацетиленовой плазмы с растущими внутри плазменного объема пылевыми частицами. Исследование проведено с помощью пространственноусредненной модели. Для анализа влияния атомов $\mathrm{Ar}^{*}$ на плотность электронов и ионов, эффективную температуру электронов и плотность радикальных и нерадикальных нейтральных частиц значения коэффициентов ионизации и диссоциации для столкновений молекул ацетилена с атомами Ar* в численных расчетах варьировались. Установлено, что столкновения атомов $\mathrm{Ar}^{*}$ с молекулами ацетилена существенно влияют на пылевую аргон-ацетиленовую плазму.

\section{ВПЛИВ АТОМІВ АРГОНУ В ЗБУДЖЕНОМУ СТАНІ НА ВЛАСТИВОСТІ АРГОН- АЦЕТИЛЕНОВОЇ ЗАПОРОШЕНОЇ ПЛАЗМИ}

\section{І.Б. Денисенко, С. Івко, М.О. Азарєнков, Г. Бурмака}

Досліджено, як дисоціація та іонізація молекул ацетилену при їх зіткненні з атомами аргону в збудженому стані Ar* можуть впливати на властивості аргон-ацетиленової плазми зі зростаючими всередині плазмового об’єму порошинками. Дослідження проведено за допомогою просторово-усередненої моделі. Для аналізу впливу атомів Ar* на густину електронів та іонів, ефективну температуру електронів та густину радикальних і нерадикальних нейтральних частинок значення коефіцієнтів іонізації і дисоціації для зіткнень молекул ацетилену з атомами Ar* у численних розрахунках варіювалися. Встановлено, що зіткнення атомів Ar* 3 молекулами ацетилену істотно впливають на запорошену аргон-ацетиленову плазму. 